\title{
FDG-PET: An Important Tool in the Diagnosis of Lung Cancer
}

\author{
Wolfgang Abenhardt \\ Münchner Onkologische Praxis Elisenhof, Munich, Germany
}

In this issue of ONKOLOGIE Huang and collegues [1] present an interesting case report of non-small cell lung cancer (NSCLC), specifically a G2 adenocarcinoma in lower left lobe of the lungs with presumable skip metastasis to a single lymph node in the upper abdomen, but without mediastinal lymph node invasion, detected by ${ }^{18} \mathrm{~F}$-fluoro-deoxy-glucose (FDG) positron emission tomography (PET). The single abdominal lesion has been confirmed immunohistologically after laparoscopic resection as metastatic lesion of this lung tumor.

With investigation by PET and computed tomography (CT) a critical upstaging has resulted from stage I to stage IV, which should be a contraindication for radical operation and indication for systemic chemotherapy. The primary lesion was located poorly marginated near the aorta in the anatomical region of the thoracic duct. Therfore, a direct infiltration of the thoracic duct must be discussed and the tumor then graded as (inoperable) T4. In contrast to hilar and mediastinal lymph nodes, lung, liver, brain, bone and adrenal glands, the abdominal lymph nodes are not typical sites for metastasis of lung cancer. This rare site of metastasis should be considered exclusively in tumors located in the left paraaortal regions. Therefore an underestimation of this manifestation in the past, as the authors suggest, is not quite presumable.

The important statement of this report, however, is the strong upgrade of the tumor stage by FDG-PET and thereby critical change of treatment. It is a common experience in PET-performing centers that FDG-PET leads to a change of treatment in $20-25 \%$ of patients, mostly those with in lung cancer, malignant lymphoma and melanoma but also in others. There is a large body of evidence that locoregional lymph node stag- ing by FDG-PET (in conjuction with CT) is significantly superior to $\mathrm{CT}$ alone with a negative predictive value for mediastinal manifestation equal or even superior to mediastinoscopy [2, 3]. FDG-PET also improves extrathoracic staging by detection of lesions missed by conventional imaging. Concerning investigational accuracy in NSCLC, FDGPET is superior to CT, and combined PET-CT is superior to both single procedures (with figures for sensitivity, specificity, positive predictive value, negative predictive value, and accuracy of $100,81,71,100$, and $87 \%$, respectively in a large current review, [4]).

Therefore, FDG-PET and CT (integrated or synchronous) should be a routine staging procedure in the diagnosis of lung cancer (NSCLC and also SCLC [5]). After a troublesome learning process of more than 15 years even the German health system will be able to recognize the importance of FDG-PET in oncology.

\section{References}

1 Huang TW, Tzao C, Chen DW, Tsai WC, Cheng YL, Lee SC: Lung cancer with isolated skip metastasis to an abdominal lymph node. Onkologie 2007;30 DOI: $10.1159 / 000103328$

2 Vansteenkiste JF, Stroobants SS: PET scan in lung cancer: current recommendations and innovation. J Thorac Oncol 2006;1:71-73.

3 Pillot G, Siegel BA, Govindan R: Prognostic value of FDG-PET in non-small cell lung cancer: a review. J Thorac Oncol 2006;1:152-159.

4 De Wever W, Vankan Y, Stroobants S, Verschakelen J: Detection of extrapulmonary lesions with integrated PET/CT in the staging of lung cancer. Eur Respir J 2007;29:995-1002.

5 Kut V, Spies W, Spies S, Gooding W, Argiris A: Staging and monitoring of small cell lung cancer using FDG-PET. Am J Clin Oncol 2007;30:45-50.

\begin{tabular}{llll}
\hline KARGER & ( 2007 S. Karger GmbH, Freiburg & & Dr. Wolfgang Abenhardt \\
Fax +49761452 0714 & Accessible online at: & Münchner Onkologische Praxis Elisenhof \\
E-mail Information@Karger.de & www.karger.com/onk & & \\
www.karger.com & & 80335 München, Germany \\
& & Tel. +49 89-45 22 560, Fax -5504242 \\
& & E-mail w.abenhardt@onkologie-elisenhof.de
\end{tabular}

